\title{
Expression of Y-box-binding protein dbpC/contrin, a potentially new cancer/testis antigen
}

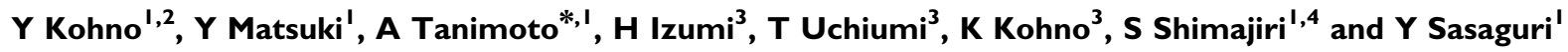 \\ 'Department of Pathology and Cell Biology, School of Medicine, University of Occupational and Environmental Health, Kitakyushu, Japan; ${ }^{2}$ Department of \\ Ophthalmology, School of Medicine, University of Occupational and Environmental Health, Kitakyushu, Japan; ${ }^{3}$ Department of Molecular Biology, School \\ of Medicine, University of Occupational and Environmental Health, Kitakyushu, Japan; ${ }^{4}$ Department of Surgical Pathology, Kyushu Koseinenkin Hospital, \\ Kitakyushu, Japan
}

Y-box-binding proteins are members of the human cold-shock domain protein superfamily, which includes $\mathrm{dbpA}$, dbpB/YB-I, and $\mathrm{dbpC/contrin.} \mathrm{dbpC/contrin} \mathrm{is} \mathrm{a} \mathrm{germ} \mathrm{cell-specific} \mathrm{Y-box-binding} \mathrm{protein} \mathrm{and} \mathrm{is} \mathrm{suggested} \mathrm{to} \mathrm{function} \mathrm{as} \mathrm{a} \mathrm{nuclear} \mathrm{transcription} \mathrm{factor}$ and RNA-binding protein in the cytoplasm. Whereas ubiquitous $\mathrm{dbpB} / \mathrm{YB}-\mathrm{I}$ expression has been well studied in various types of human carcinomas as a prognostic or predictive marker, the $\mathrm{dbpC/contrin} \mathrm{expression} \mathrm{in} \mathrm{human} \mathrm{tumour} \mathrm{cells} \mathrm{has} \mathrm{not} \mathrm{been} \mathrm{reported.}$ In this report, we provide the first evidence showing that $\mathrm{dbpC}$ was highly expressed in human testicular seminoma and ovarian dysgerminomas, and in carcinomas in other tissues and that its expression in normal tissues is nearly restricted to germ cells and placental trophoblasts. These results indicate that $\mathrm{dbpC/contrin} \mathrm{would} \mathrm{be} \mathrm{a} \mathrm{potentially} \mathrm{novel} \mathrm{cancer/testis} \mathrm{antigen.}$

British Journal of Cancer (2006) 94, 7I0-7|6. doi:I0.1038/sj.bjc.6602987 www.bjcancer.com

Published online 14 February 2006

(C) 2006 Cancer Research UK

Keywords: dbpC/contrin; human tumours; immunohistochemistry; cancer/testis antigen; cancer stem cells

Y-box-binding proteins are nucleic acid-binding proteins and are members of the human cold-shock domain protein superfamily (CSPs), which includes $\mathrm{dbpA}, \mathrm{dbpB} / \mathrm{YB}-1$, and $\mathrm{dbpC/contrin}$ (Kohno et al, 2003). The CSPs are eukaryotic homologues of bacterial cold-shock proteins, which function as RNA chaperones (Matsumoto and Wolffe, 1998). Human heat-shock proteins have been well studied; however, much is not known about the functional roles of cold-shock proteins. In general, the cold-shock response includes growth arrest and a reduction in protein synthesis in bacteria (Jolly and Morimoto, 2000). The eukaryotic Y-box-binding proteins have been not known to be involved in the cold-shock response; however, recent study indicated a block in cell proliferation after low-temperature shift in YB-1 knockout chicken cell line (Matsumoto et al, 2005).

The Y-box-binding proteins participate in various reactions, including DNA repair, transcription, and translation (Kohno et al, 2003). Of the human Y-box-binding protein family members, $\mathrm{dbpB} / \mathrm{YB}-1$ was first described in 1988 as a ubiquitously expressed transcriptional factor that can bind to the CCAAT-box of the major histocompatibility complex (MHC) class II promoter (Didier et al, 1988). The dbpA gene was first identified in 1988 (Sakura et al, 1988 ) and cloned in 1995, encoding a protein highly expressed in skeletal muscle (Kudo et al, 1995), and that of dbpC/contrin was cloned in 1999 as coding for a testis-specific protein distinct from

*Correspondence: Dr A Tanimoto, Department of Pathology and Cell Biology, School of Medicine, University of Occupational and Environmental Health, I - I Iseigaoka, Yahatanishi-ku, Kitakyushu 807-8555, Japan; E-mail: aki@med.uoeh-u.ac.jp

Received I0 October 2005; revised 4 January 2006; accepted 17 January 2006; published online 14 February 2006 other Y-box-binding proteins (Tekur et al, 1999). The ubiquitous expression of the $\mathrm{dbpB} / \mathrm{YB}-1$ gene in human normal and neoplastic tissues has been well studied and found to be closely associated with the expression of p-glycoprotein, the product of the multidrug resistance 1 (MDR1) gene, in breast cancers (Bargou et al, 1997), osteosarcomas (Oda et al, 1998), ovarian cancers (Kamura et al, 1999), and synovial sarcomas (Oda et al, 2003). It is also associated with the expression of DNA topoisomerase II and proliferating cell nuclear antigen in colon (Shibao et al, 1999) and lung (Gu et al, 2001) cancers. Thus, the nuclear localisation of $\mathrm{dbpB} / \mathrm{YB}-1$ is significantly related to malignant behaviour, and, consequently, this transcriptional factor is a tumour-biologic factor indicating a poor prognosis (Janz et al, 2002).

In contrast, the expression of $\mathrm{dbpA}$ was first reported to be restricted to the heart and skeletal muscles (Kudo et al, 1995). It functions as a transcriptional repressor of MHC I-A and vascular endothelial growth factor genes (Lloberas et al, 1995; Coles et al, 2002). A recent report indicated somatic mutations and singlenucleotide pleomorphism in the promoter of $\mathrm{dbpA}$ to be associated with hepatocarcinogenesis (Hayashi et al, 2002). On the other hand, dbpC/contrin is a germ cell-specific Y-box-binding protein and is suggested to function as a nuclear transcription factor and RNA-binding protein in the cytoplasm (Tekur et al, 1999). However, its expression and distribution have not been studied in human neoplastic tissues. In the present study, therefore, we investigated the expression and distribution of the $\mathrm{dbpA}$ and $\mathrm{dbpC/contrin} \mathrm{in} \mathrm{human} \mathrm{normal} \mathrm{and} \mathrm{neoplastic} \mathrm{tissues}$ by using antibodies raised against C-terminal synthetic peptides of these proteins.

We demonstrated that $\mathrm{dbpC}$, but not $\operatorname{dbpA}$, was highly expressed in human normal spermatogonia/spermatocytes, oocytes, and placental trophoblasts as well as in testicular 
seminoma, ovarian dysgerminomas, and various histological types of human cancer tissues. Therefore, a possibility is suggested that the $\mathrm{dbpC}$ would be a novel cancer/testis $(\mathrm{C} / \mathrm{T})$ antigen and also a marker for cancer stem cells.

\section{MATERIALS AND METHODS}

\section{Preparation of human tissue samples}

Normal human tissue samples of general organs were obtained from three autopsy cases and from non-tumour parts of surgically resected specimens (Table 1). For human neoplastic tissue samples, 123 cases of surgically resected tumours including 21 germ cell tumours of ovarian and testicular origin were examined in the Department of Pathology and Cell Biology at University of Occupational and Environmental Health in Kitakyushu, Japan (Tables 2 and 3). These cases were classified according to the World Health Organization Histological Typing of each tissue. The diagnosis was re-evaluated and confirmed by at least three boardparaffin-embedded tissue sections stained with haematoxylin and eosin $(\mathrm{H} \& \mathrm{E})$ or appropriate immunohistochemical stains.

\section{Preparation of antibodies against CSPs}

Polyclonal antibodies were raised against $\mathrm{dbpA}$ and $\mathrm{dbpC} /$ contrin by multiple immunisation of New Zealand white rabbits with synthetic peptides. The sequence of the synthetic peptide for $\mathrm{dbpA}$ was CGKEAKAGEAPTEN, and that for $\mathrm{dbpC/contrin,} \mathrm{CAPVNSGDPTT}$ TILE. The specificity of the antibodies was confirmed by Western blotting and immunostain with peptide competition (not shown).

\section{Immunohistochemistry of tissue samples}

Immunohistochemical staining was performed by using the antibody-linked dextran polymer method (Envision, DAKO, Tokyo). Deparaffinised and rehydrated $5-\mu \mathrm{m}$ sections were antigen-retrieved by heating them in Target retrieval solution (DAKO) for $20 \mathrm{~min}$, and then incubating them in $3 \% \mathrm{H}_{2} \mathrm{O}_{2}$ for $10 \mathrm{~min}$ to block endogenous peroxidase activity. The sections were thereafter rinsed and incubated with rabbit polyclonal anti-CSPs antibodies. The second antibody/peroxidase-linked polymers were then applied, and the sections were incubated with a solution consisting of $20 \mathrm{mg}$ of $3.3^{\prime}$-diaminobenzidine tetrahydrochloride, certified surgical pathologists who had examined formalin-fixed,

$65 \mathrm{mg}$ of sodium azide, and $20 \mathrm{ml}$ of $30 \% \mathrm{H}_{2} \mathrm{O}_{2}$ in $100 \mathrm{ml}$ of Tris$\mathrm{HCl}\left(50 \mathrm{mmol}^{-1}, \mathrm{pH}\right.$ 7.6). After having been counterstained with Meyer's haematoxylin, the sections were observed under a light microscope. For the CSP immunohistochemistry of normal human

Table I Distribution of dbps in human normal tissue

\begin{tabular}{|c|c|c|}
\hline & dbpA & dbpC \\
\hline \multicolumn{3}{|l|}{ Ovary } \\
\hline Oocyte & - & +++ \\
\hline Granulosa cell & - & - \\
\hline \multicolumn{3}{|l|}{ Testis } \\
\hline Spermatogonia and spermatocyte & + & +++ \\
\hline Sertoli cell & - & - \\
\hline Leydig cell & + & - \\
\hline Uterus & - & - \\
\hline Fallopian tube & - & - \\
\hline Oesophagus & + & - \\
\hline Stomach & + & - \\
\hline Small intestine & - & - \\
\hline Large intestine & - & - \\
\hline Liver & - & - \\
\hline Pancreas & - & - \\
\hline Lung - arterial smooth muscle & - & + \\
\hline Heart & ++ & + \\
\hline Skeletal muscle & ++ & + \\
\hline Aorta & - & - \\
\hline Renal tubules & - & - \\
\hline Bladder & - & - \\
\hline Spleen & - & - \\
\hline Bone marrow - megakaryocytes & - & - \\
\hline Thymus & - & - \\
\hline Brain & - & - \\
\hline Spinal cord & - & - \\
\hline Thyroid gland & - & - \\
\hline Adrenal gland & - & - \\
\hline Cortex - reticular zone & + & + \\
\hline Decidual cell & ++ & - \\
\hline Trophoblast & - & ++ \\
\hline
\end{tabular}

Table 2 Expression of $\mathrm{dbpA}$ and $\mathrm{dbpC}$ in cancer tissues

\begin{tabular}{|c|c|c|c|c|c|c|c|c|}
\hline \multirow[b]{2}{*}{ Organ } & \multirow[b]{2}{*}{ Histology } & \multirow[b]{2}{*}{ Cases } & \multicolumn{3}{|c|}{ dbpA } & \multicolumn{3}{|c|}{ dbpC } \\
\hline & & & + & ++ & +++ & + & ++ & +++ \\
\hline Ovary & Serous adenocarcinoma & 10 & I & 0 & 0 & 2 & 0 & 0 \\
\hline Stomach & Adenocarcinoma & 10 & 0 & 0 & 0 & 2 & 3 & 0 \\
\hline Colon & Adenocarcinoma & 10 & 0 & 0 & 0 & 2 & 7 & 0 \\
\hline \multirow[t]{2}{*}{ Liver } & Hepatocellular carcinoma & 10 & 0 & 0 & 0 & 0 & 0 & 0 \\
\hline & Cholangiocellular carcinoma & 10 & । & I & 0 & 2 & 6 & 0 \\
\hline Breast & Invasive ductal carcinoma & 10 & 0 & 0 & 0 & 2 & 3 & 0 \\
\hline Pancreas & Adenocarcinoma & 10 & 0 & 0 & 0 & 4 & 2 & 0 \\
\hline Kidney & Clear cell carcinoma & 10 & । & 0 & 0 & 1 & 0 & 0 \\
\hline Prostate & Adenocarcinoma & 10 & 0 & 0 & 0 & 4 & 0 & 0 \\
\hline \multirow[t]{3}{*}{ Lung } & Adenocarcinoma & 10 & 0 & 0 & 0 & 0 & 0 & 0 \\
\hline & Squamous cell carcinoma & 10 & 0 & 0 & 0 & 3 & 3 & 0 \\
\hline & Total cases & 110 & 3 & 1 & 0 & 22 & 24 & 0 \\
\hline Testis & Seminoma & 10 & 0 & 0 & 0 & 0 & 0 & 10 \\
\hline \multirow[t]{2}{*}{ Ovary } & Dysgerminoma & 3 & 0 & 0 & 0 & 0 & 0 & 3 \\
\hline & Total cases & 13 & 0 & 0 & 0 & 0 & 0 & 13 \\
\hline
\end{tabular}


Table 3 Expression of dbps in human germ cell tumours

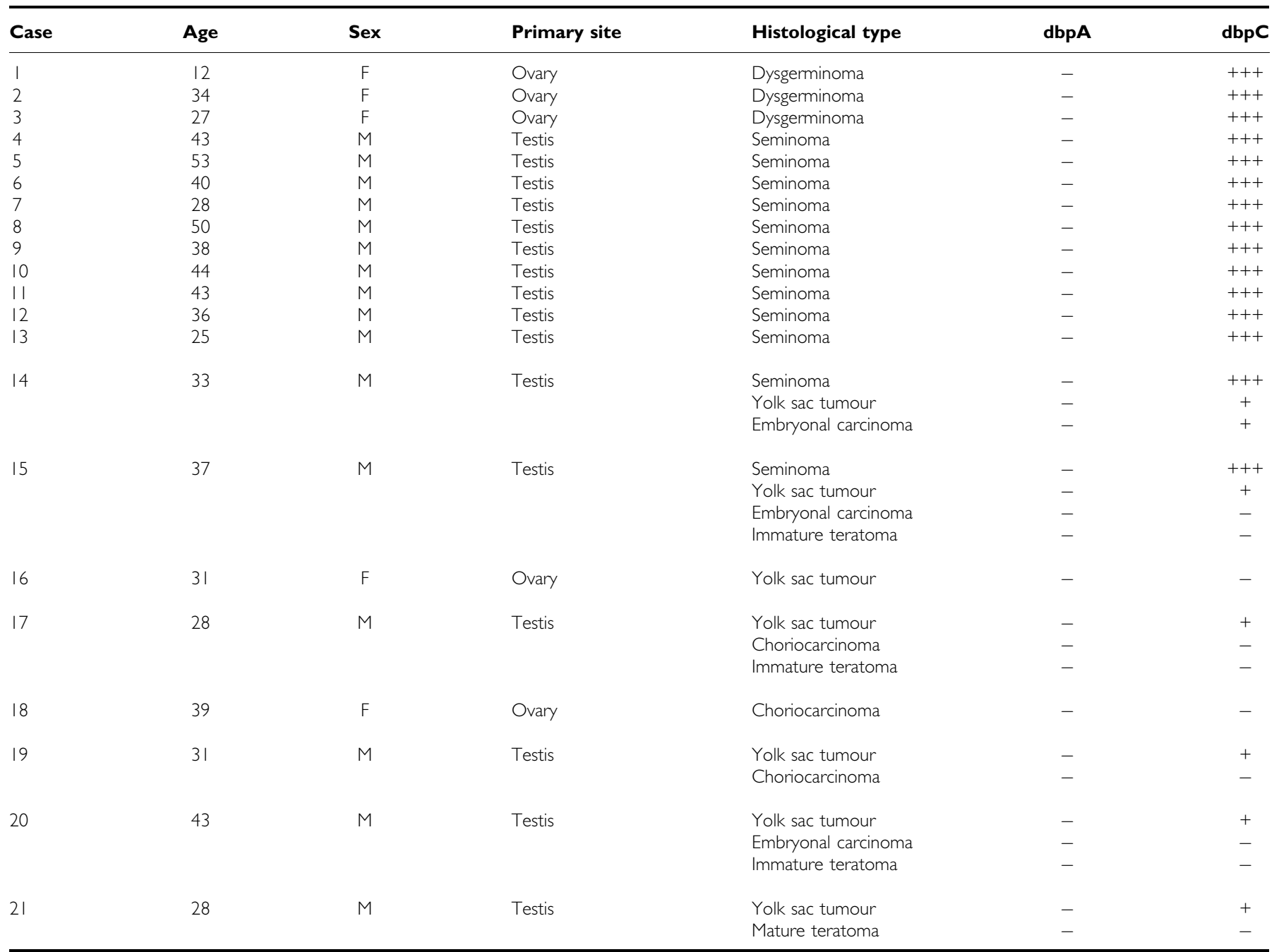

tissues, the intensity of the immunohistochemical reaction was graded into four categories: $(-)$, cells with negative staining; $(+)$, cells with a low staining intensity; $(++)$, cells with moderately stronger intensity than $(+)$ but less than $(+++)$; $(+++)$, cells with a marked staining intensity. For the neoplastic tissues, positive areas comprising less than $10 \%$ of the neoplasms were considered as negative staining. Positive areas that were equal to or more than $10 \%$ were defined as positive staining and were graded into three categories: $(+)$, positive area of $10-30 \%$; $(++)$, $30-80 \%$; $(+++)$, more than $80 \%$ positive area.

\section{Cell cultures}

Human seminoma cell lines Teral (ATCC HTB-105), NEC8 (JCRB0250), choriocarcinoma cell line NJG (IFO50322), and breast cancer cell line MCF7 cell (ATCC HTB-22) were obtained from American Type Culture Collection (Rockville, MD, USA) and maintained in RPMI1640 medium containing 10\% fetal calf serum (ICN, Costa Mesa, CA, USA) at $37^{\circ} \mathrm{C}$ in an atmosphere of $95 \%$ air and $5 \% \mathrm{CO}_{2}$.

\section{Immunocytochemistry of seminoma cell line NEC8}

Human seminoma NEC8 cells were cultured on coverslips, fixed with $95 \%$ acetone for $5 \mathrm{~min}$, and allowed to air dry. The cells were then incubated with anti-dbp antibodies for $1 \mathrm{~h}$ at room temperature (RT), washed with PBS, and reacted with fluorescein isothiocyanate-conjugated goat anti-rabbit IgG for $1 \mathrm{~h}$ at RT. After having been washed with PBS, the specimens were observed under a Nikon fluorescence microscope.

To investigate the subcellular localisation of the $\mathrm{dbpC}$ protein, we transfected human seminoma cells (NEC8) by lipofection (Gibco BRL, Grand Island, NY, USA) with plasmids expressing $\mathrm{dbpC}$ fused to green fluorescent protein (GFP-dbpC). The cells were cultured for $24 \mathrm{~h}$ after the transfection and then observed under the fluorescence microscope.

\section{Cell fractionation and Western blotting}

Cells $\left(2 \times 10^{7}\right)$ were resuspended in $2 \mathrm{ml}$ of ice-cold $10 \mathrm{~mm}$ HEPES$\mathrm{KOH}$ (pH 7.9) containing $10 \mathrm{mmoll}^{-1} \mathrm{KCl}, 0.1 \mathrm{mmoll}^{-1}$ EDTA, $0.1 \mathrm{mmoll}^{-1}$ EGTA, $1 \mathrm{mmoll}^{-1}$ dithiothreitol, and $0.5 \mathrm{mmoll}^{-1}$ phenylmethylsulphonyl fluoride (PMSF) and incubated on ice for $15 \mathrm{~min}$. The cells were then lysed by the dropwise addition of $0.6 \%$ $\mathrm{NP}-40$, and the lysates were centrifuged at $400 \mathrm{~g}$ for $10 \mathrm{~min}$ at $4{ }^{\circ} \mathrm{C}$. The supernatant was used as the cytoplasmic fraction, and the nuclear pellet was resuspended in $300 \mu \mathrm{l}$ of ice-cold $20 \mathrm{mmoll}^{-1}$ HEPES-KOH ( $\mathrm{pH} 7.9$ ) containing $0.4 \mathrm{moll}^{-1} \mathrm{NaCl}, 1 \mathrm{mmoll}^{-1}$ EDTA, $1 \mathrm{mmoll}^{-1}$ dithiothreitol, and $1 \mathrm{mmoll}^{-1} \mathrm{PMSF}$ and incubated for $15 \mathrm{~min}$ on ice with frequent gentle mixing followed 
by centrifugation for $5 \mathrm{~min}$ at $4^{\circ} \mathrm{C}$ to remove insoluble materials. The resulting supernatant was taken as the nuclear fraction. The proteins in the cytoplasmic and nuclear fractions $(100 \mu \mathrm{g})$ were separated by $10 \%$ SDS-polyacrylamide gel electrophoresis and transferred onto a polyvinylidene fluoride membrane. The membrane was immunoblotted with anti-CSP antibodies (diluted $1: 3000$ ) for $1 \mathrm{~h}$ and then developed by chemiluminescence using the ECL kit (Amersham, Piscataway, NJ, USA).

\section{RESULTS}

\section{Expression of Y-box-binding proteins in normal human tissues (Figure 1 and Table 1)}

For detection of $\mathrm{dbpA}$ and $\mathrm{dbpC}$ expression in normal human tissues, non-tumour areas of surgically resected tumours and tissues from autopsy cases were examined immunohistochemically. The dbpA protein was predominantly distributed in the cardiomyocytes and striated muscle cells (not shown). In the ovary and testis, $\mathrm{dbpA}$ was expressed in the spermatocytes located in the inner area of the seminiferous tubules but not in oocytes (Figure 1). The $\mathrm{dbpC/contrin} \mathrm{protein} \mathrm{was} \mathrm{markedly} \mathrm{expressed} \mathrm{in} \mathrm{oocytes} \mathrm{and}$ testicular germ cells in the stage of spermatogonia to spermatocyte,

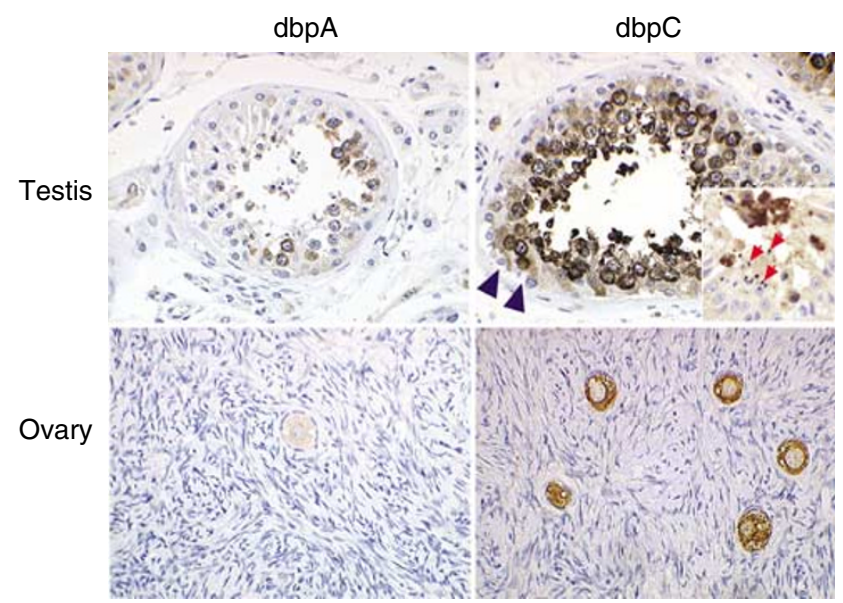

Figure I Expression of $\mathrm{dbpA}$ and $\mathrm{dbpC}$ in normal human testis and ovary. Note the extensive expression of $\mathrm{dbpC}$ in the spermatogonia to spermatocytes and in the oocytes. Some cells show a nuclear localisation of the $\mathrm{dbpC}$ protein. Sertoli cells (arrowheads) and spermatids (arrows in the inset) are negative for the dbps. On the other hand, the cells located in the inner parts of the seminiferous tubules (spermatocytes) are positive for dbpA.
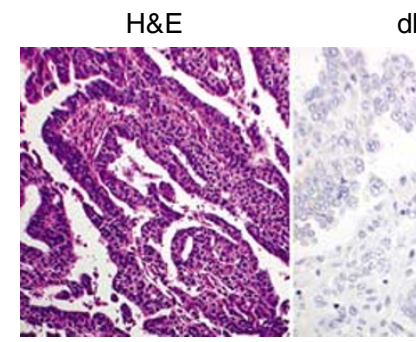

dbpA

$\mathrm{dbpC}$

Figure 2 Expression of $\mathrm{dbp} A$ and $\mathrm{dbpC}$ in a human ovarian adenocarcinoma. The carcinoma cells are weakly positive for $\mathrm{dbpC}$, but negative for $\mathrm{dbp} A$. some of which showed nuclear localization of the protein. The vascular smooth muscle cells in the pulmonary artery, myocardium, and skeletal muscle were also $(+)$ positive for $\mathrm{dbpC}$ (not shown), but epithelial cells in respiratory, gastrointestinal, and urogenital tracts were negative. Placental trophoblasts were also positive for $\mathrm{dbpC}$ (not shown). The results on the immunolocalisation of these dbps in normal human tissues are summarised in Table 1.

\section{Expression of $\mathrm{dbpA}$ and $\mathrm{dbpC}$ in human carcinomas in various organs (Figure 2 and Table 2)}

As the expression of $\mathrm{dbpB} / \mathrm{YB}-1$ has been well studied in many types of human carcinoma cells (Bargou et al, 1997; Oda et al, 1998; Kamura et al, 1999; Shibao et al, 1999; Gu et al, 2001; Oda et al, 2003), we focused on the expression of $\mathrm{dbpA}$ and $\mathrm{dbpC}$ in human tumour cells in this report. We collected the cancer tissues of the alimentary and respiratory tracts, breast, kidney, prostate, and ovary (10 cases each). As a result, no dbpA was detected in these cancer cells, except for two rare cases of cholangiocellular carcinoma, one renal cell carcinoma, and one ovarian serous cystadenocarcinoma, in which the degree of positive staining was $(+)$ or $(++)$. In contrast, $\mathrm{dbpC}$ was expressed in many types of carcinoma cells at a relatively higher frequency than for $\mathrm{dbpA}$; however, all staining was $(+)$ or $(++)$. The frequency of dbpCpositive tumours varied among the histological types. Hepatocellular carcinomas and lung adenocarcinomas were negative in all 10 cases, whereas adenocarcinomas of the colon and cholangiocellular carcinomas exhibited higher frequencies for expressing $\mathrm{dbpC}$ (nine out of 10 and eight out of 10 , respectively). In total, approximately $40 \%$ ( 46 out of 110 ) of the carcinomas were positive for $\mathrm{dbpC}$. Even in the negative cases (less than $10 \%$ positive cells), however, scattered individual cells were positive for $\mathrm{dbpC}$ in the most carcinoma tissues examined (not shown). Figure 2 shows a representative case of dbpC-positive ovarian serous cystadenocarcinoma. The results for all carcinomas examined are summarised in Table 2 .

\section{Expression of $\mathrm{dbpA}$ and $\mathrm{dbpC}$ in human germ cell tumours (Figure 3 and Table 3 )}

All the testicular seminomas and ovarian dysgerminomas tested (cases 1-13), as well as seminoma components in testicular mixed germ cell tumours (cases 14 and 15), showed strong $(+++$ ) granular cytoplasmic staining with anti-dbpC antibody, whereas they were negative for dbpA (Figure 3 ). In other types of germ cell tumours, for example, the tumour cells of yolk sac tumours (cases 14-21) and embryonal carcinoma (case 14), positive immunoreactions for $\mathrm{dbpC}$ were focal; however, the cells of choriocarcinomas and of mature or immature teratomas were negative. The
$H \& E$

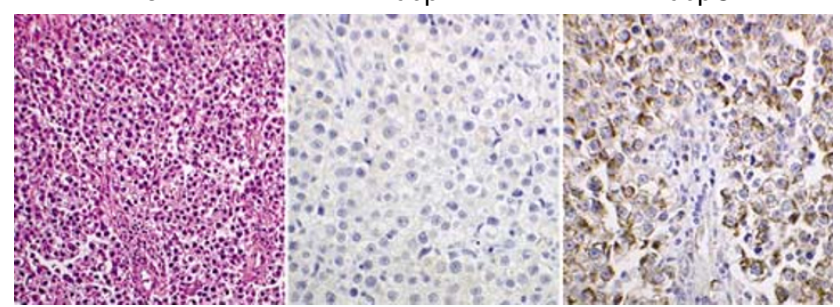

Figure 3 Expression of $\mathrm{dbpA}$ and $\mathrm{dbpC}$ in human testicular seminoma. This H\&E section demonstrates a typical feature of testicular seminoma. The $\mathrm{dbpC}$ protein, but not dbpA, is intensely expressed in the cytoplasm of the tumour cells. 
A
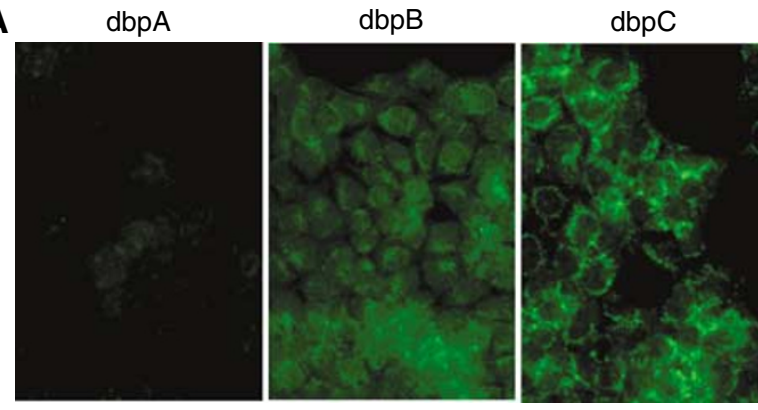

B

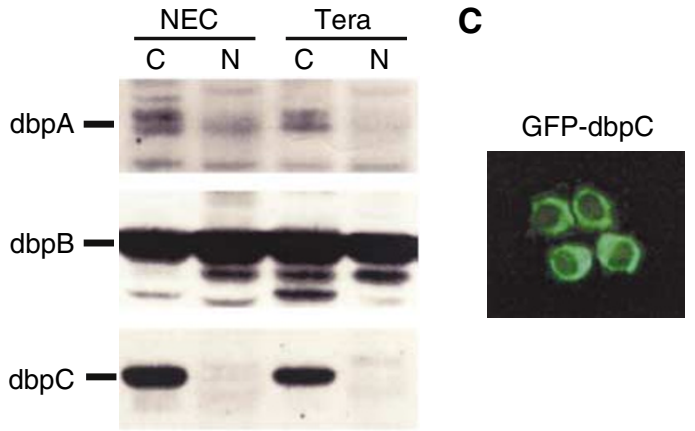

Figure 4 Expression of $\mathrm{dbpC}$ in cultured human seminoma cells. (A) Demonstration of $\mathrm{dbpA}, \mathrm{dbpB}$, and $\mathrm{dbpC}$ immunofluorescence in cultured seminoma NEC8 cells. The dbpC is localised in the cytoplasm of the NEC8 cells, whereas dbpA and $\mathrm{dbpB}$ expression is weak. (B) Western blotting analysis of $\mathrm{dbp}$ expression. $\mathrm{dbpC}$ is expressed in the cytoplasmic fraction (C) but not in the nuclear fraction (N) from human seminoma NEC8 or Tera cells. dbpB is expressed in both cytoplasmic (C) and nuclear (N) fractions. The expression of $\mathrm{dbpA}$ is weakly detected in the cytoplasm or nuclei. (C) Expression of GFP-dbpC in NEC8 cells. The green fluorescence indicating the protein is predominantly located in the cytoplasm.

results of immunohistochemistry for $\mathrm{dbpA}$ and $\mathrm{dbpC}$ in the germ cell tumours are summarised in Table 3.

\section{Analysis of dbpC expression in human seminoma cell lines}

The immunofluorescence staining of the seminoma cell lines showed marked expression of $\mathrm{dbpC}$ in the cytoplasm, but only weak expression for dbpA and dbpB (NEC8 in Figure 4A). Western blotting analysis showed cytoplasmic distribution of $\mathrm{dbpC}$ protein in both seminoma cell lines examined (NEC8 and Tera), whereas $\mathrm{dbpB}$ was localised in both cytoplasmic and nuclear fractions (Figure 4B). When NEC8 cells were transfected with plasmids expressing the GFP-dbpC fusion protein, the green fluorescence was mainly localised in the cytoplasm, indicating a predominant localisation of $\mathrm{dbpC}$ even in the condition of overexpression (Figure 4C).

\section{DISCUSSION}

The expression of many genes is regulated at the level of transcription during embryogenesis and spermatogenesis. Translational control, however, represents a major mechanism of gene regulation in germ cell differentiation and early embryogenesis and in late spermatogenesis (Ritcher, 1993; Schafer et al, 1995; Hecht, 1998). Germ cells store masked mRNAs, and the unmasking of the mRNAs for protein synthesis plays an important role in the meiotic progression of oocytes to eggs and in the late stage of spermatogenesis (Hecht, 1995; Eddy and O’Brien, 1997). This translational control is likely to be regulated by a number of RNA- binding proteins (Cooke and Elliott, 1997). dbpC, a mammalian homologue of the Xenopus germ cell-specific Y-box protein, may serve a similar function, as it is present exclusively in postmeiotic round spermatids in rodent testis and in diplotene-stage and mature oocytes ( $\mathrm{Gu}$ et al, 1999; Tekur et al, 1999). Recently, growing numbers of genes that are expressed in male germ cells and malignancies have been designated as CT genes, by which a common functional pathway between spermatogenesis and tumorigenesis (e.g. progression of meiosis and polyploidy, respectively) would be explainable (Old, 2001; Simpson et al, 2005). Therefore, the study of the expression of $\mathrm{dbpC}$ in malignancies might provide clues for understanding the shared characters between spermatogenesis and tumorigenesis.

Here, we demonstrated for the first time that $\mathrm{dbpC}$ is highly expressed in human normal germ cells and trophoblasts, but rarely in no-germline normal tissues, as well as testicular seminomas, ovarian dysgerminomas, and many cancer cells in other organs.

\section{Expression of dbps in normal and neoplastic tissues}

The present study showed unique distribution of the $\operatorname{dbpA}$ and $\mathrm{dbpC}$ proteins in normal human tissues. $\mathrm{dbpA}$ was distributed in the heart, skeletal muscle, and decidual cells, whereas $\mathrm{dbpC}$ was predominantly localised in testicular and ovarian germ cells, and in trophoblasts (Table 1). In the human testis, $\mathrm{dbpC}$ was expressed intensely in the cells undergoing transition from spermatogonia to spermatocytes. In the neoplastic tissue, dbpA was detected in only a few carcinoma cases among more than 100 cancer cases. In contrast, $\mathrm{dbpC}$ was extensively expressed in the seminomas and dysgerminomas. In other organs, many types of cancers were also positive for $\mathrm{dbpC}$ (Tables 2 and 3 ). Thus, $\mathrm{dbpC}$ showed restricted expression in normal tissues but a wide distribution in malignancies. This contrasts well with the ubiquitous expression of $\mathrm{dbpB}$ in normal and neoplastic cells (Kohno et al, 2003).

\section{$\mathrm{dbpC}$ as a potential cancer/testis antigen}

Antigens that show expression restricted to normal testicular germ cells, trophoblasts, and malignancies are designated as CT antigens (Old, 2001; Scanlan et al, 2004; Kalejs and Erenpreisa, 2005; Simpson et al, 2005). As features in germ cells corresponding to those in cancer cells include immortalisation to transformation, meiosis to aneuploidy, and migration to metastasis, it is thought that genetic alteration in cancer cells is the result of the activation of normally silent germline genes. The CT genes support the theory that the aberrant expression of germline genes in cancer cells reflects the reactivation of the silenced gametogenic programmes in terms of tumorigenesis (Simpson et al, 2005). At present, $44 \mathrm{CT}$ antigen families are known to be expressed in testicular spermatogonia, spermatocytes, or spermatids and in malignancies of various histological types including lung, gastrointestinal, urogenital cancers (Jungbluth et al, 2000, 2002; Scanlan et al, 2004; Kalejs and Erenpreisa, 2005). The biological function of CT antigens in either germ cells or cancer cells is not yet clearly understood; however, some of the CT antigens are suggested to be translational or transcriptional regulatory factors or RNA-binding proteins (Simpson et al, 2005).

On the other hand, the dbpC protein was initially found as a product of mouse testicular cDNA and shown to be a mammalian homologue of Xenopus germ cell-specific nucleic acid-binding protein FRGY2 (Gu et al, 1999). It is expressed in mouse round spermatids and mature oocytes and is known to interact with both DNA and RNA. In the present study, we also demonstrated the expression of $\mathrm{dbpC}$ to be predominantly in human male germ cells and placental trophoblasts as well as in various malignancies. These features of the tissue distribution and nucleic acid-binding capacity in relation to spermatogenesis are very similar to those of 
other CT antigens. Although $\mathrm{dbpC}$ was also expressed in non-germ cells (myocardium, skeletal muscle, vascular smooth muscle cells in the lung, and adrenal cortical cells), its distribution was more restricted than that of $\mathrm{dbpB}$, which is ubiquitously expressed in normal human tissues (Kohno et al, 2003). Thus, taken together, our results indicate that the $\mathrm{dbpC}$ would be potentially a novel CTassociated antigen.

As the expression of the CT antigens is detected in spermatogonia or spermatogonial stem cells, the CT antigens could be stem cell markers for tumour cells (Simpson et al, 2005). In fact, immunohistochemical analysis has shown that CT antigens such as MAGE-1, MAGE-3, NY-ESO-1, and CT7 are frequently found in only a small proportion of cancer tissues (Jungbluth et al, 2000, 2002), an indication that the cancers contain both stem cells and differentiated cells (Simpson et al, 2005). In terms of human testicular tumours, many CT antigens including MAGE, GAGE, PAGE-1, SSX2, NY-ESO-1, LAGE-1, and SCP-1 are also demonstrated to have higher frequency of expression in seminomas than in non-seminomas (Yuasa et al, 2001). Therefore, these results suggest that less-differentiated seminomas would contain more CT antigen-positive stem cells than any other germ cell tumour or cancer. In the present study, the seminomas and dysgerminomas showed a diffuse and intense expression with the highest frequency
(100\%) for dbpC among the tumours tested including other nonseminoma germ cell tumours and carcinomas. Even in the carcinomas classified as negative for $\mathrm{dbpC}$ because of less than $10 \%$ positive cells, scattered dbpC-positive cells were detected (not shown). dbpC would thus be not only a CT antigen but also a marker of cancer stem cells.

\section{Subcellular localisation of $\mathrm{dbpC}$ in seminoma cells}

The Western blotting analysis demonstrated that the $\mathrm{dbpC}$ protein was detected in the cytoplasmic fraction of seminoma cell lines (Figure 4B), and the cytoplasmic localisation of $\mathrm{dbpC}$ was confirmed by exogenous overexpression of GFP-dbpC protein in the NEC8 cells (Figure 4C). These findings indicate that $\mathrm{dbpC}$ might function mainly in the cytoplasm and be related to the stability of mRNA and translational regulation in seminoma cells (Gu et al, 1999).

In summary, we demonstrated that $\mathrm{dbpC}$ was dominantly expressed in normal germ cells and in various malignancies. As the distribution of this protein is very similar to that of CT antigens, we suggest $\mathrm{dbpC}$ to be a novel $\mathrm{CT}$ antigen and a marker for cancer stem cells.

\section{REFERENCES}

Bargou RC, Jurchott K, Wagener C, Bergmann S, Metzner S, Bommert K, Mapara MY, Winzer KJ, Dietel M, Dorken B, Royer HD (1997) Nuclear localization and increased levels of transcription factor YB-1 in primary human breast cancers are associated with intrinsic MDR1 gene expression. Nat Med 3: $447-450$

Coles LS, Diamond P, Lambrusco L, Hunter J, Burrows J, Vadas MA, Goodall GJ (2002) A novel mechanism of repression of the vascular endothelial growth factor promoter, by single strand DNA binding cold shock domain (Y-box) proteins in normoxic fibroblasts. Nucleic Acids Res 30: $4845-4854$

Cooke HJ, Elliott DJ (1997) RNA-binding proteins and human male infertility. Trends Genet 13: 87-89

Didier DK, Schiffenbauer J, Woulfe SL, Zacheis M, Achwartz BD (1988) Characterization of the cDNA encoding a protein binding to the major histocompatibility complex II Y box. Proc Natl Acad Sci USA 85: $7322-7326$

Eddy EM, O’Brien DA (1997) Gene expression during mammalian meiosis. In Current Topics in Developmental Biology Handel MA (ed) Vol 37 pp 141 -200. San Diego, CA: Academic Press

Gu C, Oyama T, Osaki T, Kohno K, Yasumoto K (2001) Expression of Y box-binding protein-1 correlates with DNA topoisomerase II $\alpha$ and proliferating cell nuclear antigen expression in lung cancer. Anticancer Res 21: $2357-2362$

Gu W, Tekur S, Reinbold R, Eppig JJ, Choi YC, Zheng JZ, Murray MT, Hecht NB (1999) Mammalian male and female germ cells express a germ cell-specific Y-box protein, MSY2. Biol Reprod 20: 135-144

Hayashi J, Kajino K, Umeda T, Takano S, Arakawa Y, Kudo M, Hino O (2002) Somatic mutation and SNP in the promoter of dbpA and human hepatocarcinogenesis. Int J Oncol 21: $847-850$

Hecht NB (1995) The making of a spermatozoon: a molecular perspective. Dev Genet 16: $95-103$

Hecht NB (1998) Molecular mechanisms of male germ cell differentiation. BioEssays 20: $555-561$

Janz M, Harbeck N, Dettmar P, Berger U, Schmidt A, Jurchott K, Schmitt M, Royer HD (2002) Y-box factor YB-1 predicts drug resistance and patient outcome in breast cancer independent of clinically relevant tumor biologic factors HER2, uPA and PAI-1. Int J Cancer 97: $278-282$

Jolly C, Morimoto RI (2000) Role of the heat shock response and molecular chaperones in oncogenesis and cell death. J Natl Cancer Inst 92: $1564-1572$

Jungbluth AA, Chen YT, Busam KJ, Coplan K, Kolb D, Iversen K, Williamson B, Van Landeghem FK, Stockert E, Old LJ (2002) CT7
(MAGE-C1) antigen expression in normal and neoplastic tissues. Int $J$ Cancer 99: 839-845

Jungbluth AA, Stockert E, Chen YT, Kolb D, Iversen K, Coplan K, Williamson B, Altorki N, Busam KJ, Old LJ (2000) Monoclonal antibody MA454 reveals a heterogeneous expression pattern of MAGE-1 antigen in formalin-fixed paraffin embedded lung tumours. $\mathrm{Br} J$ Cancer 83: $493-497$

Kalejs M, Erenpreisa J (2005) Cancer/testis antigens and gametogenesis: a review and 'brain-storming' session. Cancer Cell Int 5: 4-14

Kamura T, Yahata H, Amada S, Ogawa S, Sonoda T, Kobayashi H, Mitsumoto M, Kohno K, Kuwano M, Nakano H (1999) Is nuclear expression of Y-box-binding protein a new prognostic factor in ovarian serous adenocarcinoma? Cancer 85: 2450-2454

Kohno K, Izumi H, Uchiumi T, Ashizuka M, Kuwano M (2003) The pleiotropic functions of the $y$-box-binding protein, YB-1. BioEssays 25: $691-698$

Kudo S, Mattei MG, Fukuda M (1995) Characterization of the gene for $\mathrm{dbpA}$, a family member of the nucleic-acid-binding proteins containing a cold-shock domain. Eur J Biochem 231: $72-82$

Lloberas J, Maki RA, Celada A (1995) Repression of major histocompatibility complex I-A $\alpha$ gene expression by $\mathrm{dbpA}$ and $\mathrm{dbpB}$ (mYB-1) proteins. Mol Cell Biol 15: 5092-5099

Matsumoto K, Tanaka KJ, Tsujimoto M (2005) An acidic protein, YBAP1, mediates the release of YB-1 from mRNA and relieves the transcriptional repression activity of YB-1. Mol Cell Biol 25: 1779-1792

Matsumoto K, Wolffe AP (1998) Gene regulation by Y-box proteins: coupling control of transcription and translation. Trends Cell Biol 8: $318-323$

Oda Y, Ohnishi Y, Saito T, Hinoshita E, Uchiumi T, Kinukawa N, Iwamoto Y, Kohno K, Kuwano M, Tsuneyoshi M (2003) Nuclear expression of Y-box-binding protein-1 correlates with P-glycoprotein and topoisomerase II $\alpha$ expression, and with poor prognosis in synovial sarcoma. $J$ Pathol 199: $251-258$

Oda Y, Sakamoto A, Shinohara N, Ohga T, Uchiumi T, Kohno K, Tsuneyohi M, Kuwano M, Iwamoto Y (1998) Nuclear expression of YB-1 protein correlates with P-glycoprotein expression in human osteosarcoma. Clin Cancer Res 4: 2273-2277

Old LJ (2001) Cancer/testis (CT) antigens - a new link between gametogenesis and cancer. Cancer Immun 1: 1-7

Ritcher JD (1993) Translational control in development: a perspective. Dev Genet 14: $407-411$

Sakura H, Maekawa T, Imamoto F, Yasuda K, Ishll S (1988) Two human genes isolated by a novel method encode DNA-binding 
proteins containing a common region of homology. Gene 73: $499-507$

Scanlan MJ, Simpson AJG, Old LJ (2004) The cancer/testis genes: review, standardization, and commentary. Cancer Immun 4: 1-15

Schafer M, Nayernia K, Engel W, Schafer U (1995) Translational control in spermatogenesis. Dev Biol 172: $344-352$

Shibao K, Takano H, Nakayama Y, Okazaki K, Nagata N, Izumi H, Uchiumi T, Kuwano M, Kohno K, Itoh H (1999) Enhanced coexpression of YB-1 and DNS topoisomerase II $\alpha$ genes in human colorectal carcinomas. Int $J$ Cancer 83: $732-737$
Simpson AJG, Caballero OL, Jungbluth A, Chen YT, Old LJ (2005) Cancer/testis antigens, gametogenesis and cancer. Nat Rev Cancer 5: $615-625$

Tekur S, Pawlak A, Guellaen G, Hecht NB (1999) Contrin, the human homologue of a germ-cell Y-box-binding protein: cloning, expression, and chromosomal localization. J Andol 20: 135-144

Yuasa T, Okamoto K, Kawakami T, Mishina M, Ogawa O, Okada Y (2001) Expression patterns of cancer testis antigens in testicular germ cell tumors and adjacent testicular tissue. J Urol 165: $1790-1794$ 